\title{
The Performance of Thirty-Eight Evapotraspiation Methods against the Penman Montieth Method
}

\section{DOI : 10.36909/jer.13251}

I Wayan Sutapa*, Saparuddin, Yassir Arafat, Sance Lipu, Nina B. Rustiati, I Putu Hendra Adi Pratama

Department of Civil Engineering, Engineering Faculty, Tadulako University, Indonesia

Email: wsutapa@yahoo.com; Corresponding Author

\begin{abstract}
Evapotranspiration is an important parameter to know in the management of agricultural water resources. There are several methods for estimating evapotranspiration (ETo). The FAO Penman-Monteith method is considered the universal standard for estimating ETo, however, the climate parameter data needed to calculate the ETo of the FAO Penman-Monteith method are not always available, so it is necessary to evaluate performance using several ETo equations as a comparison in estimating evapotranspiration. This study aims to find the performance of the ETo 38 empirical method against the FAO Penman Monteith method and the climatological data parameters that most influence the accuracy of the calculations. The data used is in the form of climatological data for Bora Station which represents land and settlement areas, Boladangko Station representing mountainous areas and Singkoyo Station representing coastal areas with an observation period of 32 years (1986-2017). The performance of the 38 empirical methods was evaluated using the PE, RMSE, MAE, MR and slope methods. The results of this study indicate that: the Makkink method, Abtew1, Irmak et al., Tabari \& Talaee1, Valiantzas1 and Abtew3 showed excellent performance, while the WMO and Mahringer methods performed poorly in the three research locations; the number of climatological parameters used had no significant effect on the ETo results obtained. The use of climatological parameters in the form of temperature and solar radiation in the ETo calculation has the greatest effect on the accuracy of the ETo value.
\end{abstract} Keywords: evapotranspiration; Penman-Monteith; empirical method, performance 


\section{INTRODUCTION}

There are several methods for estimating evapotranspiration (ETo), but their performance in different environments varies, as they all have an empirical background. The FAO PenmanMonteith method has been considered the universal standard for estimating ETo for more than a decade. This method considers many climatological parameters related to the evapotranspiration process, net radiation, temperature, vapor pressure deficit, and wind speed, so it gives very good results when compared to other methods. (ASCE-EWRI, 2005) (Paulo C. Sentelhas, et al., 2010)

Koffi Djaman et al. (2014) in their research produced the Hargreaves method, modified Hargreaves, Ravazzani and Tralkovic with the highest percentage error of estimate (PE). On the other hand, the calculation results of the Makkink-Hansen, Oudin and Turc equations are under the ETo reference. Temperature-based equations, such as Romenenko and Schendel's results are also quite good. The Trabert and Mahringer mass transfer equations also perform well in comparison to the Penman-Monteith equation (Djamana, et al., 2015).

Xinyi Song et al (2018) in their research resulted in the Valiantzas2, Romanenko2 and HMakkink methods recommended as alternative methods during the plant growth period, while the Turc and Hargreaves-Samani methods had significant errors. The Valiantzas2 and HMakkink methods are the most optimal methods to estimate the ET0 value in agricultural areas. Based on the output from the FAO Penman-Monteith method, the ET0 value is the most sensitive to temperature (Xinyi Song, et al., 2018).

To our knowledge, there are no reports of studies evaluating the performance of the reference evapotranspiration equation at study sites where irrigated rice production is the main activity of river populations. The purpose of this study was to find out the performance of the ETo 38 empirical method against the FAO Penman-Monteith method and the climatological data parameters that most influence the accuracy of the calculations. 


\section{MATERIALS AND METHODS \\ Study description}

This research was conducted in three locations that have different location characteristics, namely Bora Village which represents land and settlement areas, Boladangko Village which represents mountainous areas and Kulawi Village which represents coastal areas. The three locations are in Central Sulawesi Province, Indonesia. The data needed in this study are climatological data with observations of 25 years and 32 years which are obtained from the Sulawesi III River Basin Office, Indonesia. The location of the research and the data on the climatology are presented in the following figure and table:
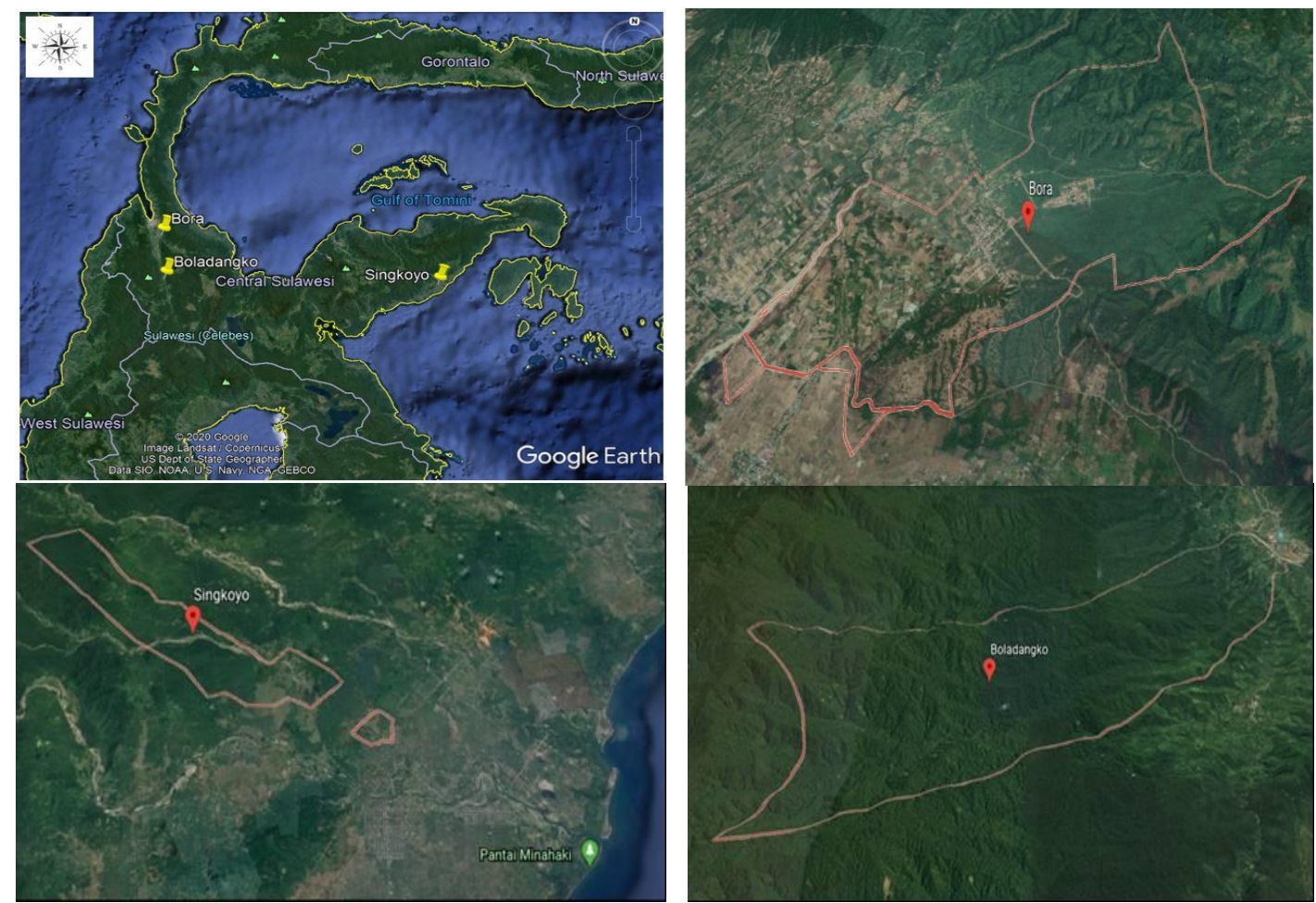

Figure 1. Research location

Table 1. Climatology station names and positions

\begin{tabular}{|c|c|c|c|c|c|}
\hline No. & Station & Location & $\begin{array}{c}\begin{array}{c}\text { Period } \\
\text { (year) }\end{array} \\
\end{array}$ & Position & $\begin{array}{c}\begin{array}{c}\text { Seawater } \\
\text { level }\end{array} \\
\end{array}$ \\
\hline \multirow{2}{*}{1} & \multirow{2}{*}{ Singkoyo } & \multirow{2}{*}{$\begin{array}{c}\text { Singkoyo } \\
\text { Watershed }\end{array}$} & $1986-2017$ & $01^{0} 26^{\prime} 51^{\prime \prime}$ South Latitude & \multirow{2}{*}{$+11.00 \mathrm{~m}$} \\
\hline & & & (32 years) & $122^{0} 20^{\prime} 09^{\prime \prime}$ East Longitude & \\
\hline \multirow{2}{*}{2} & \multirow{2}{*}{$\begin{array}{l}\text { Boladangko/ } \\
\text { Kulawi }\end{array}$} & \multirow{2}{*}{$\begin{array}{c}\text { Miu } \\
\text { Watershed }\end{array}$} & $1986-2017$ & $01^{0} 26^{\prime} 55.4^{\prime \prime}$ South Latitude & \multirow{2}{*}{$+600.00 \mathrm{~m}$} \\
\hline & & & (32 years) & $119^{0} 59^{\prime} 7.6^{\prime \prime}$ East Longitude & \\
\hline 3 & Bora & & $1993-2017$ & $01^{0} 11^{\prime} 39^{\prime \prime}$ South Latitude & $+75.00 \mathrm{~m}$ \\
\hline
\end{tabular}




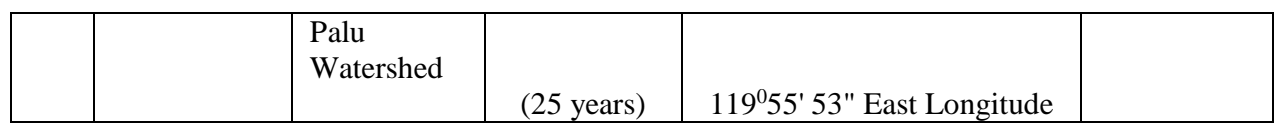

\section{Reference to the evapotranspiration equation}

The empirical methods used in the calculation of evapotranspiration (ETo) are:

\section{FAO Penman-Monteith Method}

The evapotranspiration of the FAO Penman-Monteith method is calculated by equations (Allen, R.G, et al., 1998) (Sutapa, et al., 2020; Sutapa, 2014; Sutapa, 2015a; Sutapa, 2015b; Sutapa, 2015c; Sutapa \& Ishak, 2016; Sutapa, 2017; Sutapa, et al., 2018; Sutapa, et al., 2019) (Djamana, et al., 2015) (Manik, et al., 2012) (Sentelhas, et al., 2010) (Fisher \& Pringle, 2013) (Sudarshan Prasad \& Vishal Kumar, 2013) (H. Tabari, et al., 2013) (Paulo C. Sentelhas, et al., 2010) (Xinyi Song, et al., 2018) :

$E T o=\frac{0,408 \Delta(R n-G)+\gamma\left(\frac{900}{T_{\text {mean }}+237}\right) u_{2}\left(e_{S}-e_{a}\right)}{\Delta+\gamma\left(1+0,34 u_{2}\right)}$

2. Dalton Method (Dalton J., 1802) (H. Tabari, et al., 2013):

$$
\text { ETo }=(3.648+0.7223 u)\left(e_{s}-e_{a}\right)
$$

3. Trabert Method (Trabert, W., 1896) (Djamana, et al., 2015) (H. Tabari, et al., 2013):

$$
\text { ETo }=0.408 \times 0.3075\left(e_{s}-e_{a}\right) u^{0.5}
$$

4. Meyer Method (Meyer A, 1926) (H. Tabari, et al., 2013):

$$
\text { ETo }=(3.75+0.5026 u)\left(e_{s}-e_{a}\right)
$$

5. Rohwer Method (Rohwer C., 1931) (H. Tabari, et al., 2013):

$$
\text { ETo }=(3.3+0.89 u)\left(e_{s}-e_{a}\right)
$$

6. Blaney Criddle Method (Blaney, 1950) (H. Tabari, et al., 2013) (Xinyi Song, et al., 2018):

$$
E T o=p\left(0.46 T \_m e a n+8\right)
$$

7. Albrecht Method (Albrecht, 1950) (H. Tabari, et al., 2013):

$$
E T o=(1.005+2.97 u)\left(e_{-}(s)-e_{-} a\right)
$$

8. Makkink Method (Makkink, 1957) (Djamana, et al., 2015) (Xinyi Song, et al., 2018):

$$
\text { ETo }=0,61 \frac{\Delta}{\Delta+\gamma} \frac{R_{S}}{\Lambda}-0,12
$$

9. Ivanov Method (Soewarno, 2000):

$$
\text { ETo }=0.0018(25+T)(100-R H)
$$

10. Romanenko Method (Romanenko, 1961) (Djamana, et al., 2015) (H. Tabari, et al., 2013) (Xinyi Song, et al., 2018):

$$
E T o=0.0018\left(T \_m e a n+\llbracket 25\right) \rrbracket \wedge 2(100-R H)
$$


11. Jensen \& Haise Method (Jensen \& Allen, 1963) (H. Tabari, et al., 2013):

$$
E T o=(0.0252 T+0.078) R s
$$

12. Brockamp \& Wenner Method (B. \& H., 1963) (H. Tabari, et al., 2013):

$$
\text { ETo }=20.543 u^{0.456}\left(e_{s}-e_{a}\right)
$$

13. Penman Method (Penman, 1963) (Djamana, et al., 2015) (H. Tabari, et al., 2013):

$$
\text { ETo }=\left(2.625+\frac{0.000479}{u}\right)\left(e_{s}-e_{a}\right)
$$

14. World Meteorological Organization-WMO Method (WMO, 1966) (H. Tabari, et al., 2013):

$$
\text { ETo }=(1.298+0.934 u)\left(e_{s}-e_{a}\right)
$$

15. Schendel Method (Schendel U, 1967) (Djamana, et al., 2015):

$$
\text { ETo }=16 \frac{T_{\text {mean }}}{R H}
$$

16. Mahringer Method (Mahringer, 1970) (H. Tabari, et al., 2013):

$$
\text { ETo }=2.8597 u^{0.5}\left(e_{s}-e_{a}\right)
$$

17. Caprio Method (Caprio, 1974):

$$
\text { ETo }=(0.01092708 T+0.0060706) R s
$$

18. Hargreaves Method (Hagreaves, 1974) (Sentelhas, et al., 2010) (Paulo C. Sentelhas, et al., 2010):

$$
E T o=3.96+0.966 F b(1.87 T+32) 0.166(100-R H)^{0.5}
$$

19. Hargreaves and Samani Method (Hargreaves \& ZA, 1985) (Djamana, et al., 2015)

(Sentelhas, et al., 2010) (H. Tabari, et al., 2013) (Paulo C. Sentelhas, et al., 2010):

$$
\text { ETo }=0,0023 \times R_{a} \times \sqrt{T D} \times(T+17,8)
$$

20. Modified Penman Method (Usman, 2001) (Xinyi Song, et al., 2018)

$$
E T o=c(W \cdot R n+(1-W) f(u)(e a-e d)
$$

21. Allen Method (Allen, 1993):

$$
E T o=0.408 \times 0.0029 R s(T+20)(T \max -T \min )^{0.4}
$$

22. Abtew 1 Method (Abtew W., 1996):

$$
\text { ETo }=\frac{\operatorname{Tmax}}{K} \frac{R s}{\lambda}
$$

23. Abtew 2 Method (Abtew W., 1996):

$$
\text { ETo }=0.408 \times 0.01786 \times R s \times \operatorname{Tmax}
$$

24. Abtew 3 Method (Abtew W., 1996):

$$
E T o=0.52 \frac{R s}{\lambda}
$$

25. Droogers and Allen Method (Droogers \& RG., 2002):

$$
E T o=0.00102 R s(T+16.8)(T \max -T \min )^{0.5}
$$

26. Irmak et al. Method (Irmak, et al., 2003): 
$E T o=-0.611+0.149 R s+0.079 T$

27. Trajkovic Method (Trajkovic \& Kolakovic, 2007) (Djamana, et al., 2015) (H. Tabari, et al., 2013):

ETo $=0.0023 R a($ Tmean +17.8$)(\text { Tmax }- \text { Tmin })^{0.424}$

28. Tabari and Talaee 1 Method (Tabari \& PH., 2011):

ETo $=-0.642+0.174 R s+0.0353 T$

29. Tabari and Talaee 2 Method (Tabari \& PH., 2011):

ETo $=-0.478+0.156 R s-0.0112$ Tmax +0.0733 Tmin

30. Valiantzas 1 Method (Valiantzas, 2012) (Djamana, et al., 2015) (Xinyi Song, et al., 2018): ETo $=0.0393 R s(\text { Tmean }+9.5)^{0.5}-0.19 R s^{0.6} \varphi^{0.15}+0.0061($ Tmean + 20) $(1.12 \text { Tmean }- \text { Tmin }-2)^{0.7}$

31. Valiantzas 2 Method (Valiantzas, 2012) (Djamana, et al., 2015) (Xinyi Song, et al., 2018): ETo $=0.0393 R s(\text { Tmean }+9.5)^{0.5}-0.19 R s^{0.6} \varphi^{0.15}+0.078($ Tmean +20$)\left(1-\frac{R H}{100}\right)$

32. Valiantzas 3 Method (Valiantzas, 2012) (Xinyi Song, et al., 2018):

$E T o=0.0393 R s(\text { Tmean }+9.5)^{0.5}-2.4\left(\frac{R s}{R a}\right)^{2}-($ Tmean +20$)\left(1-\frac{R H}{100}\right)(0.024-0.1$ Waero $)$

33. Valiantzas 4 Method (Valiantzas, 2012) (Xinyi Song, et al., 2018):

$$
\begin{aligned}
& \text { ETo }=0.051(1-\alpha) R s(\text { Tmean }+9.5)^{0.5}-2.4\left(\frac{R s}{R a}\right)^{2}+0.048(\text { Tmean }+20)(1- \\
& \left.\frac{R H}{100}\right)(0.5+0.536 u 2)+0.00012 z
\end{aligned}
$$

34. Valiantzas 5 Method (Valiantzas, 2012) (Xinyi Song, et al., 2018):

$$
\begin{gathered}
\text { ETo }=0.051(1-\alpha) R s(\text { Tmean }+9.5)^{0.5}-0.188(\text { Tmean }+13)\left(\frac{R s}{R a}-0.194\right)(1- \\
\left.0.00015(\text { Tmean }+45)^{2} \frac{R H}{100}\right)^{0.5}-0.0165 R s u^{0.7}+0.0585(\text { Tmean }+ \\
\text { 17) } u^{0.75} \frac{\left\{\left[\left(1+0.00043(\text { Tmax }- \text { Tmin })^{2}\right)^{2}\right]-\frac{R H}{100}\right\}}{\left(1+0.00043(\text { Tmax }- \text { Tmin })^{2}+0.0001 z\right.}
\end{gathered}
$$

35. Ravazzani et al. Method (G., et al., 2012) (Djamana, et al., 2015):

$$
E T o=(0.817+0.00022 Z) 0.0023 R a(\text { Tmean }+17.8)(\text { Tmax }- \text { Tmin })^{0.5}
$$

36. Berti et al. Method (Berti, et al., 2014) (Djamana, et al., 2015):

$$
\text { ETo }=0.00193 R a(\text { Tmean }+17.8)(\text { Tmax }- \text { Tmin })^{0.517}
$$

37. Ahooghalandari et al. 1 Method (M.Ahooghalandari, et al., 2016):

$$
\text { ETo }=0.252 \times 0.408 R a+0.221 \text { Tmean }\left(1-\frac{R H}{100}\right)
$$

38. Ahooghalandari et al. 2 Method (M.Ahooghalandari, et al., 2016):

$$
\text { ETo }=0.29 \times 0.408 R a+0.15 \operatorname{Tmax}\left(1-\frac{R H}{100}\right)
$$


39. Dorji et al. Method (Dorji, et al., 2016):

$$
E T o=0.002 \times 0.408 R a(T+33.9)(T \max -T \min )^{0.296}
$$

\section{Evaluation criteria}

The ETo 38 empirical evaluation of the Penman-Monteith FAO Method was carried out in the following ways (Wilmort, 1982) (Tumiar Katarina Manik, et al., 2012):

a. Percentage Error Of Estimate (PE)

$$
P E=\left(\frac{P a v-O a v}{O a v}\right) 100 \%
$$

b. Root Mean Squared Error (RMSE)

$$
R M S E=\sqrt{\sum_{k=0}^{n} \frac{(P i-O i)^{2}}{n}}
$$

c. Mean Absolute Error (MAE)

$$
M A E=n^{-1} \sum_{1}^{n}(P i=O i)
$$

d. Mean Ratio (MR)

$$
M R=n^{-1} \sum_{1}^{n} \frac{P i}{O i}
$$

e. Slope

$$
\mathrm{Y}=\mathrm{aX}+\mathrm{c}
$$

The value of the evaluation criteria above is made a matrix of their respective value ranges as shown in the following table:

Table 2. Evaluation criteria value

\begin{tabular}{|c|c|c|c|c|c|c|}
\hline \multicolumn{5}{|c|}{ Range of value } & \multirow{2}{*}{ Interpretation } & Value \\
\hline PE & RMSE & MAE & MR & SLOPE & Very good & 5 \\
\hline$<20$ & $<0.5$ & $<0.5$ & $>1.2$ & $>1.6$ & Good & 4 \\
\hline $20-40$ & $0.5-1.0$ & $0.5-1.0$ & $0.9-1.2$ & $1.3-1.6$ & Enough & 3 \\
\hline $40-60$ & $1.0-1.5$ & $1.0-1.5$ & $0.6-0.9$ & $1.0-1.3$ & Bad & 2 \\
\hline $60-80$ & $1.5-2.0$ & $1.5-2.0$ & $0.3-0.6$ & $0.7-1.0$ & Very bad & 1 \\
\hline$>80$ & $>2.0$ & $>2.0$ & $<0.3$ & $<0.7$ & \\
\hline
\end{tabular}


The performance of an empirical method against the FAO Penman-Monteith method is determined based on the total value of the evaluation criteria $(\mathrm{PE}+\mathrm{RMSE}+\mathrm{MAE}+\mathrm{MR}+$ Slope). The categories are presented in the following table:

Table 3. Performance value

\begin{tabular}{|c|c|}
\hline Value & Interpretation \\
\hline$>22$ & Very good \\
\hline $18-22$ & Good \\
\hline $13-17$ & Enough \\
\hline $8-12$ & Bad \\
\hline$\leq 7$ & Very bad \\
\hline
\end{tabular}

RESULTS AND DISCUSSION

The results of calculations from 38 empirical methods and Penman-Monteith FAO can interpret the values of PE, RMSE, MAE MR and Slope as follows:

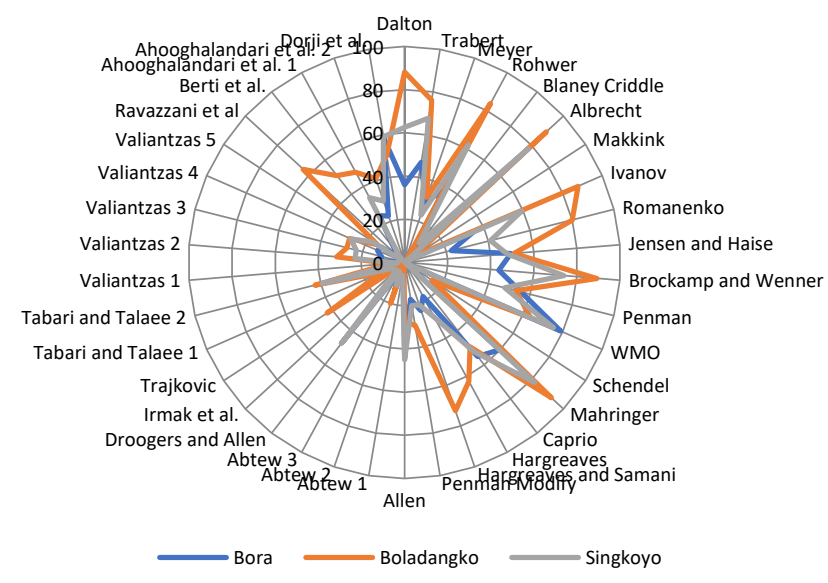

Figure 2. Value of PE in the three climatology station locations

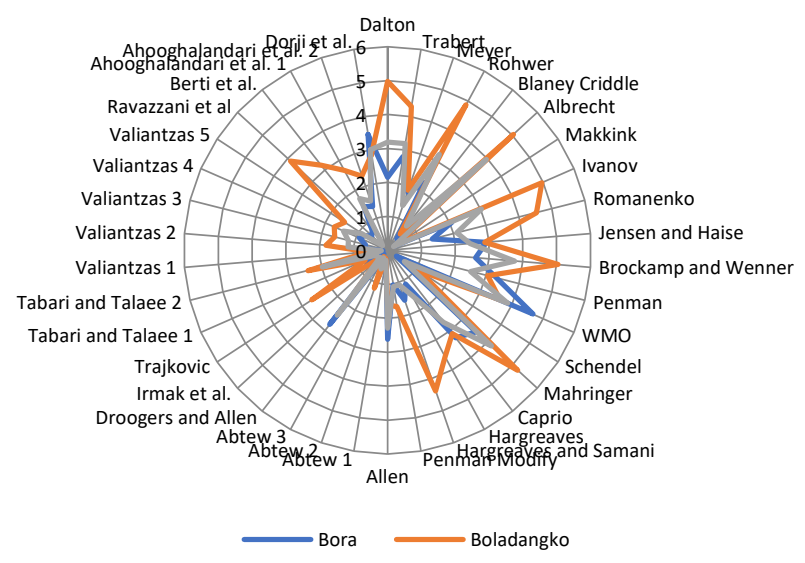

Figure 3. Value of RMSE in the three climatology station locations 


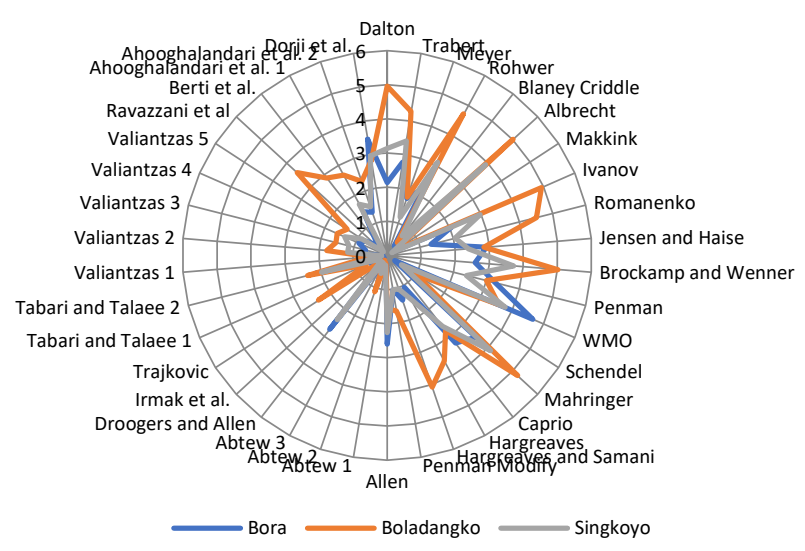

Figure 4. Value of MAE in the three climatology stations

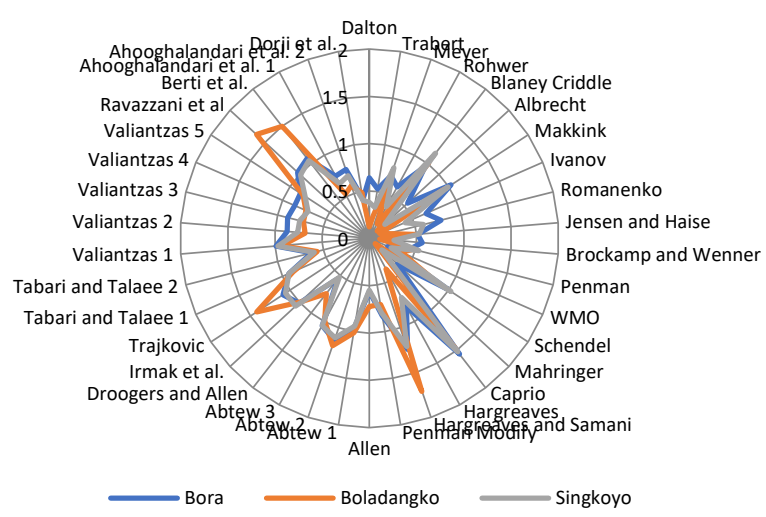

Figure 5. Value of MR in the three climatology stations

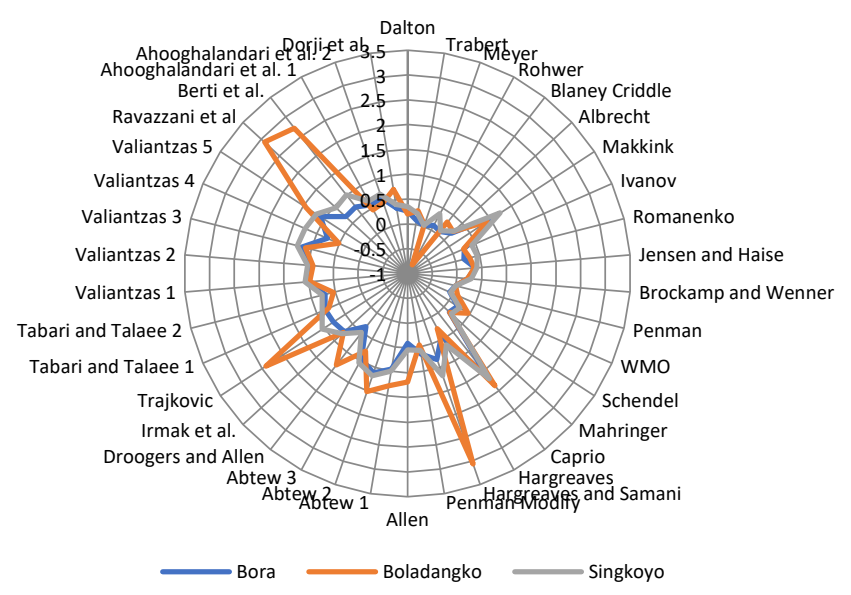

Figure 6. Values of Slope in the three climatological stations

The results of the calculation of each value of the evaluation criteria (PE, RMSE, MAE, MR, and Slope) are then made the interpretation value by adding up the value of these criteria, as presented in the following figures: 


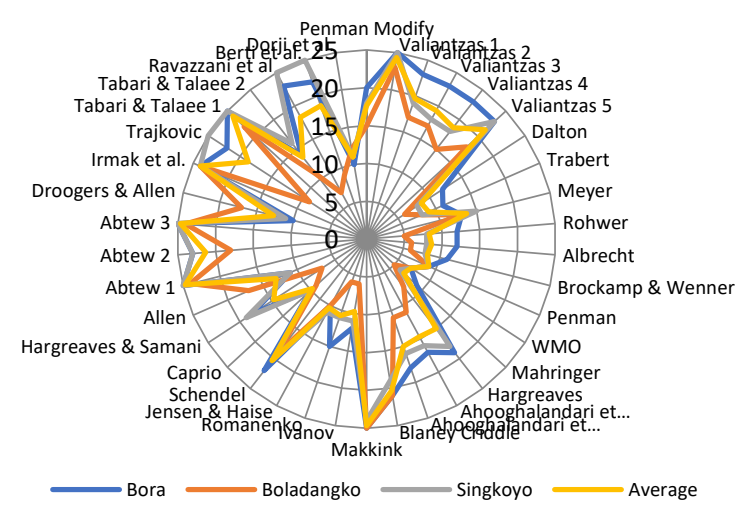

Figure 7. Performance of the empirical method on the Penman-Monteith Method

The Bora climatology station which represents the land/settlement area of 38 alternative methods used in this study Abtew 1, Abtew 2, Abtew 3, Valiantzas 1, Valiantzas 2, Valiantzas 3, Valiantzas 4, Valiantzas 5, Makkink, Irmak et al. Tabari \& Talaee 1 showed excellent performance with a total score between 23 - 25. The modified Penman method, Ahooghalandari et al. 2, Hargreaves, Blaney Criddle, Schendel, Hargreaves \& Samani, Trajkovic, Berti et al. Showed good performance with a total score between 18 - 22. Meyer, Ahooghalandari et al. 1, Romanenko, and Tabari \& Talaee 2 showed fairly good results with a total score of $13-17$. The Dalton, Trabert, Rohwer, Albrecht, Brockamp \& Wenner, Penman, Mahringer, Ivanov, Jensen \& Haise, Caprio, Allen, method Droogers \& Allen, Dorji et al. shows poor performance with a total score between 9 - 12. While the worst is the WMO Method with a total score of 7.

The Boladangko climatology station, which represents a mountainous area of 38 alternative methods used in this study, the methods of Makkink, Abtew 1, Abtew3 and Irmak et al., Showed excellent performance with a total value between $23-25$. Valiants method 5, Blaney Cridle, Schendel, Abtew2, and Tabari \& Talaee1 showed good performance with a total score between 18 - 22. The Modified Penman Method, Valiantzas4, Valiantzas3, Valiantzas 2, Meyer, Allen, and Droogers \& Allen showed quite good performance with a total score between 13-17. Trabert, Penman, Hagreaves, Ahooghalandari et al. 1, Ahooghalandari et al. 2, Jensen \& Haise, 
Caprio, Trajkovic, Tabari \& Talaee 2, Berti et al., Dorji et al. shows poor performance with a total score between 8 - 12. The method of Dalton, Rohwer, Albrecht, Brockamp \& Wenner, WMO, Mahringer, Ivanov, Romanenko, Hargreaves \& Samani, Ravazzani et al., shows very poor performance with a total score of $5-7$.

The Singkoyo climatology station which represents the coastal area of 38 alternative methods used in this study is the Valiantzas 5, Makkink, Abtew1, Abtew2, Abtew3, Irmak et al., Trajkovic, Tabari \& Talaee 1, Valiantzas1, Ravazzani et al. al. showed excellent performance with a total value between 23 - 25. The modified Penman method, Valiantzas4, Valiantzas3, Valiantzas2, Blaney Cridle, Schendel, and Hargreaves \& Samani showed good performance with a total value between 18-20. Meyer, Ahooghalandari et al. . 1, Ahooghalandari et al. 2, Tabari \& Talaee 2 performed quite well with a total score of 15-16. Dalton, Trabert, Rohwer, Albrecht, Brockamp \& Wenner, Penman, Ivanov, Romanenko, Jensen \& Haise, Caprio, Allen, Droogers $\&$ Allen, Dorji et al. shows poor performance with a total score between $8-11$. The WMO and Mahringer methods show very poor performance with a total score between $6-7$.

The total mean value of the three stations (Bora, Boladangko, Singkoyo) representing the condition of the Central Sulawesi region from 38 methods used by the Makkink Method, Abtew1, Abtew3, Irmak et al., Tabari \& Talaee1, and Valiantzas1 showed very good performance. The modified Penman method, Valiantzas4, Valiantzas4, Valiantzas2, Ravazzani et al., Berti et al. show good performance. Meyer, Hagreaves, Ahooghalandari et al. 1, Ahooghalandari et al. 2, Hagreaves \& Samani, Allen, Droogers \& Allen, and Tabari \& Talaee 2 performed well. Dalton, Trabert, Rohwer, Albrecht, Brockamp \& Wenner, Penman, Ivanov, Romanenko, Jensen \& Haise, Caprio, Dorji et al. shows poor performance. The WMO and Mahringer methods are the worst of all methods used in the calculation of evapotranspiration when compared to the Penman-Monteith FAO Method.

\section{CONCLUSION}


The conclusion of this study is to evaluate the performance of 38 reference evapotranspiration equations against the FAO Penman-Monteith equation at three locations with the following descriptions:

1. The performance for the combined value of the three locations can be explained that the Makkink Method, Abtew1, Abtew3, Irmak et al., Tabari \& Talaee1, and Valiantzas1, Modified Penman, Valiantzas4, Valiantzas4, Valiantzas2, Ravazzani et al., Berti et al., Meyer , Hagreaves, Ahooghalandari et al. 1, Ahooghalandari et al. 2, Hagreaves \& Samani, Allen, Droogers \& Allen, and Tabari \& Talaee 2 performed well, while the Dalton, Trabert, Rohwer, Albrecht, Brockamp \& Wenner, Penman, Ivanov, Romanenko, Jensen \& Haise Methods, Caprio, Dorji et al., WMO and Mahringer performed poorly.

2. The number of climatological parameters used in the calculation of evapotranspiration does not have a significant effect on the results obtained.

3. The use of temperature and solar radiation data in the calculation of evapotranspiration is an empirical method that has the greatest influence on the accuracy of the evapotranspiration value.

\section{AKNOWLEDGEMENT}

The authors would like to thank the Undergraduate Study Program (S1), Department of Civil Engineering, Faculty of Engineering, Tadulako University, Indonesia for the financial support. Thanks, are also conveyed to the Office of the Sulawesi River Region III Office for supporting the data so that this research can be carried out.

\section{REFERENCES}

Abtew W., 1996. Evapotranspiration measurements and modeling for three wetland systems in South Florida. J. Am. Water Resour. Assoc., Volume 32, pp. 465-473.

Albrecht, F., 1950. DieMethoden zur Bestimmung Verdunstung der Natürlichen Erdoberfläche. s.1.:Archives Meteorological Geophysics B2. 
Allen, R.G, Perriera L.S., Raes D. \& Smith M., 1998. Crop evapotranspiration-guidelines for computing crop water requirement-FAO irrigation and drainage paper No. 56, Rome: Food Agriculture Organization of the United Nation..

Allen, R., 1993. Evaluation of a temperature difference method for computing grass reference evapotranspiration, Rome: Technical report, Water Resources Development and Management Service, and Water Development Division, FAO.

ASCE-EWRI, 2005. The ASCE standardized reference evapotranspiration equation. In: Allen, R.G., Walter, I.A., Elliot, R.L., et, al.(Eds.), Environmental and Water Resources Institute (EWRI) of the American Society of Civil. Engineers, ASCE.. s.l.: American Society of Civil Engineers (ASCE), Reston, VA..

B., B. \& H., W., 1963. Verduns tungs messungen auf den Steiner See bei Munster. Dt. Gewa sserkundl Mitt., Volume 7, pp. 149-154.

Berti, et al., 2014. Assessing reference evapotranspiration by the hargreaves method in northeastern Italy. Agric. Water Manage, Volume 140, pp. 20-25.

Blaney, H. I. C. W., 1950. Determining water requirements in irrigation areas from climatological and irrigation data. s.1.:USDA (SCS) TP-96.

Caprio, J., 1974. The solar thermal unit concept in problems related to plant development and potential evapotranspiration. H. Lieth (Ed.), Phenology and seasonality modeling. New York: Ecological Studies, Springer Verlag.

Dalton J., 1802. Experimental essays on the constitution of mixed gases; on the force of steam of vapor from waters and other liquids in different temperatures, both in a Torricellian vacuum and in the air on evaporation and on the expansion of gases by heat. Mem. Manch. Lit. Philos. Soc., Volume 5, pp. 535-602.

Djamana, K. et al., 2015. Evaluation of sixteen reference evapotranspiration methods under Sahelian conditions in the Senegal River Valley. Journal of Hydrology: Regional Studies, Volume 3, pp. 139-159.

Dorji, U., JE., O. \& MS., S., 2016. Water balance in the complex mountainous terrain of Bhutan and linkages to land use. J. Hydrology, Volume 7, pp. 55-68.

Droogers, P. \& RG., A., 2002. Estimating reference evapotranspiration under inaccurate data conditions. Irrig. Drain Syst., Volume 16, pp. 33-45.

Fisher, D. K. \& Pringle, H. C., 2013. Evaluation of alternative methods for estimating reference evapotranspiration. Agricultural Sciences, 4(8A), pp. 51-60.

G., R., C., C., S., M. \& P., G., 2012. Modified Hargreaves Samani equation for the assessment of reference evapotranspiration in alpine river basins. J. Irrig, Drain. Eng. ASCE, 138(7), pp. 592-599. 
H. Tabari, M. E. Grismer \& S. Trajkovic, 2013. Comparative analysis of 31 reference evapotranspiration methods under humid conditions. Irrigation Science, Volume 31, pp. 107117.

Hagreaves, G., 1974. Moisture availability and crop production. Trans ASAE, Volume 18, pp. 980-984.

Hargreaves, G. \& ZA, S., 1985. Reference crop evapotranspiration from temperature. Applied Engineering in Agriculture, 1(2), pp. 96-99.

Irmak, S., RG, A. \& J., J., 2003. Solar and net radiation-based equations to estimate reference evapotranspiration in humid climates. J. Irrig. Drain Eng., Volume 129, pp. 336-347.

Jensen, H. \& Allen, R. G., 1963. Evapotranspiration and Irrigation Water Requirements, New York: ASCE Manuals and Report on Engineering practices No. 70.

M.Ahooghalandari, M., K. \& ME., J., 2016. Developing equations for estimating reference evapotranspiration in Australia. Water Resour. Manag., 30(11), pp. 3815-3828.

Mahringer, W., 1970. Verdunstungsstudien am neusiedler see. Theor. Appl. Clim., 18(1), pp. $1-20$.

Makkink, G., 1957. Testing The Penman Formula Using Lysimeters. J. Int. Water Engineering, Volume 11, pp. 277-288.

Manik, T. K., Rosadi, R. B. \& Karyanto, A., 2012. Evaluation of the Penman-Monteith Method in Estimating the Standard Evapotranspiration Rate (ET0) in the Lowlands of Lampung Province, Indonesia. JTEP Journal Keteknikan Pertanian, 26(2).

Meyer A, 1926. Über einige Zusammenhange zwischen Klima und boden in Europa. s.1.:Chem. Erde.

Paulo C. Sentelhas, Terry J. Gillespie \& Eduardo A. Santos, 2010. Evaluation of FAO Penman-Monteith and alternative methods for estimating reference evapotranspiration with missing data in Southern Ontario, Canada. Agricultural Water Management, Volume 97, pp. 635-644.

Penman, L. H., 1963. Vegetation and hydrology. Harpenden, England: Tech. Comm. No. 53, Commonwealth Bureau of Soils.

Rohwer C., 1931. Evaporation from the free water surface. s.1.: USDA Tech. Null..

Romanenko, V. A., 1961. Computation of the autumn soil moisture using a universal relationship for a large area. s.l., Proceedings, Ukrainian Hydrometeorological Research Institute.

Schendel U, 1967. Vegetations wasserverbrauch und wasserbedarf. s.1.:Habilitation, Kiel.

Sentelhas, P. C., Gillespie, T. J. \& Santos, E. A., 2010. Evaluation of FAO Penman-Monteith and alternative methods for estimating reference evapotranspiration with missing data in Southern Ontario, Canada. Agricultural Water Management, Volume 97, pp. 635-644. 
Soewarno, 2000. Operational Hydrology. Bandung, Indonesia: Citra Aditya.

Sudarshan Prasad \& Vishal Kumar, 2013. Evaluation of FAO-56 Penman-Monteith and alternative methods for estimating reference evapotranspiration using limited climatic data at Pusa. Journal of Agrometeorology, 15(1), pp. 22-29.

Sutapa, I. W., 2014. Application model Mann-Kendall and Sen'S (Make sens) for detecting climate change. The infrastructure Journal Civil Engineering University of Tadulako, Volume 4, pp. 31-40.

Sutapa, I. W., 2015a. Study water availability of Malino River to meet the need of water requirement in district Ongka Malino, Central Sulawesi of Indonesia. International Journal of Engineering and Technology, 7(3), pp. 1069-1075.

Sutapa, I. W., 2015b. Modeling discharge of Bangga watershed under climate change. Applied Mechanics and Materials Journal, Volume 776, pp. 133-138.

Sutapa, I. W., 2015c. Long-Term Trend Climatology in Sigi, Central Sulawesi province. Surabaya, s.n., pp. 267-277.

Sutapa, I. W., 2017. Effect of Climate Change on Recharging Groundwater in Bangga Watershed, Central Sulawesi of Indonesia. Environ. Eng.Res.J., 22(1), pp. 87-94.

Sutapa, I. W., Darman, S., Nurdin, D. \& Fathurrahman, 2018. An assessment of the drought index as the impact of climate change using MockWyn-UB model. International Journal Engineering and Technology, 10(3), pp. 692-698.

Sutapa, I. W., Darman, S., Nurdin, D. \& Fathurrahman, 2019. Effects of Land Cover, Evapotranspiration, and Rainfall on Total Runoff in the Gumbasa River Basin, Central Sulawesi, Indonesia. International Journal of Engineering and Technology (IJET), 11(6), pp. 1182-1191.

Sutapa, I. W. \& Ishak, M. G., 2016. Application of non-parametric test to detect trend rainfall in Palu Watershed, Central Sulawesi, Indonesia. International Journal Hydrology Science and Technology, 6(3), pp. 238-253.

Sutapa, I. W., Saparuddin \& Wicana, S., 2020. The sensitivity of methods for estimating potential evapotranspiration to climate change. Malang, Indonesia, IOP Conference Series: Earth and Environmental Science, pp. 1-9.

Tabari, H. \& PH., T., 2011. Local calibration of the Hargreaves and Priestley-Taylor equations for estimating reference evapotranspiration in arid and cold climates of Iran based on the Penman-Monteith model. J. Hydrol. Eng., Volume 16, pp. 837-845.

Trabert, W., 1896. Neue beobachtungen uber verdamp fungs gesch windig keiten. s.1.:Meteolo. Z..

Trajkovic, S. \& Kolakovic, S., 2007. Evaluate the reference equation for evapotranspiration under humid conditions. Water Resources Management, Volume 23, pp. 3057-3067. 
Tumiar Katarina Manik, R. Bustomi Rosadi \& Agus Karyanto, 2012. Evaluation of the Penman-Monteith Method in estimating the standard evapotranspiration rate (ET0) in the lowlands of Lampung Province, Indonesia. Journal Keteknikan Pertanian, 26(2), pp. 121128.

Usman, 2001. Sensitivity Analysis of Several Potential Evapotranspiration Estimation Methods to Climate Change. Journal Natur Indonesia, 6(2), pp. 91-98.

Valiantzas, J. D., 2012. Simple ET forms of Penman's equation without wind and/or humidity data. J. Irrig. Drain Eng., Volume 10, pp. 1-8.

Wilmort, C., 1982. Some comments on the evaluation of model performance. Bulletin of American meteorological society, 63(11), pp. 1309-1313.

WMO, 1966. Measurement and estimation of evaporation and evapotranspiration. s.1.:Tech. Pap. (CIMO-Rep) 83. Genf.

Xinyi Song, Fan Lu, Weihua Xiao \& Kui Zhu, 2018. Performance of 12 reference evapotranspiration estimation methods compared with the Penman-Monteith method and the potential influences in northeast China. Meteorological Application, Volume 26, pp. 83-96. 